\title{
O drama do antitestemunho: Świadkowie albo Nasza Mała Stabilizacja (As Testemunhas ou Nossa Pequena Estabilização), de Tadeusz Różewicz ${ }^{1}$
}

Marcelo Paiva de Soura ${ }^{2}$

"E daí?"

(Idiotismo brasileiro)

Resumo: Após algumas considerações iniciais sobre a recepção do teatro de Tadeusz Różewicz no Brasil, propõe-se a tradução de um fragmento da peça Świadkowie albo Naša Mała Stabilizacja (As Testemunhas ou Nossa Pequena Estabilização), de 1962. A obra é objeto de uma breve discussão crítica introdutória, e também são discutidas, sucintamente, as balizas e metas que nortearam o processo tradutório, com especial ênfase em seu aspecto de in(ter)venção intercultural, estética e política. Palavras-chave: Świadkowie albo Nasza Mała Stabilizacja (As Testemunhas ou Nossa Pequena Estabilização); Tadeusz Różewicz; drama polonês moderno; tradução.

Abstract: After a few considerations about the reception of Tadeusz Różewicz's theatre in Brazil, I present my translation into Portuguese of a fragment of the play Świadkowie albo Nasza Mała Sta-

1 Este trabalho é um dos resultados das atividades que desenvolvi, ao longo de 2019, em um pós-doutorado no Programa de Pós-Graduação em Estudos da Tradução (POET) da Universidade Federal do Ceará, sob a supervisão do Prof. Dr. Walter Carlos Costa.

2 Professor do Departamento de Polonês, Alemão e Letras Clássicas e da Pós-Graduação em Letras da Universidade Federal do Paraná e tradutor. Bolsista PQ-2 do Conselho Nacional de Desenvolvimento Científico e Tecnológico. 
bilizacja (The Witnesses or Our Little Stabilization), from 1962. The play is the subject of a short introductory discussion, and the criteria and goals that guided the translation process are also briefly discussed, with special emphasis on its aspect of intercultural, aesthetic and political in(ter)vention.

Keywords: Świadkowie albo Nasza Mała Stabilizacja (The Witnesses or Our Little Stabilization); Tadeusz Różewicz; Polish modern drama; translation.

O retrospecto, por ora, não é de encher os olhos, mas pelo menos cabe afirmar que a recepção da dramaturgia de Tadeusz Różewicz (1921-2014) já deu seus primeiros passos no Brasil. Em diferentes âmbitos. A escrupulosa erudição de Nélson de Araújo, por exemplo, em sua valiosíssima História do Teatro, não deixou passar despercebida a fundamental contribuição różewicziana à efervescência criativa nos palcos da Polônia durante as décadas de 1960-1970. Apontando certeiramente, de um lado, vários nomes de destaque no domínio da encenação - desde Tadeusz Kantor, Józef Szajna e Jerzy Grotowski, até Erwin Axer, Andrzej Wajda, Konrad Swinarski e Jerzy Jarocki -, de outro lado Araújo também se volta, com igual perspicácia, para a seara da criação dramatúrgica. Entre os autores em maior evidência no "clímax de experimentalismo" (ARAÚJO, 1991, p. 409) do período mencionado, são aludidos em primeiro lugar Stanisław Ignacy Witkiewicz e Witold Gombrowicz, cuja tardia consagração cênica, dentro e fora das fronteiras polonesas, justamente então se desenrolava. ${ }^{3} \mathrm{E}$ em seguida o estudioso se detém na nova "geração de dramaturgos surgida (...) depois do último conflito mundial" (p. 419), salientando dessa vez os perfis de Sławomir Mrożek e Tadeusz Różewicz.

Dada a natureza de um compêndio como a História do Teatro, em que disputam a primazia, parágrafo a parágrafo, o ímpeto da abrangência e o imperativo da síntese, seria quiçá querer demais do livro esperar dele especial aprofundamento na abordagem de um universo vastamente desconhecido em nosso meio. Louve-se, antes, o trabalho de pesquisa exemplar de seu autor, que não se poupou o esforço de buscar e transmitir informação fidedigna sobre a exuberante produção cênica da Polônia na segunda metade do séc. XX. Różewicz, que é também uma das vozes

3 Recordemos que a maior parte da produção dramatúrgica de Witkiewicz (1885-1939) data de fins da década de 1910 a meados de 1920. Gombrowicz (1904-1969), por seu turno, publica sua primeira peça no final dos anos 1930. Inovadores radicais, de uma desnorteante originalidade, não por acaso ambos só alcançam pleno reconhecimento crítico - e a merecida aclamação nos palcos - a partir dos anos de 1960. 
mais notáveis da lírica polonesa do pós-guerra, observa Nélson Araújo, escreveu - entre outras - peças como O Fichário, As Testemunhas e O Casamento Branco, ${ }^{4}$ obras que se afastam de qualquer "Realismo convencional" (p. 420), assevera o estudioso, graças a uma estruturação dramática "impregnada de poesia" (p. 420). Logo adiante, debruçados sobre uma amostra do texto różewicziano em tradução para a língua portuguesa, teremos chance de retomar essa breve ponderação e de seguir a pista fornecida por Araújo.

Resta ainda assinalar, porém, que a incipiente circulação de Różewicz como dramaturgo em nosso país não se limitou apenas aos territórios acadêmicos. Fato alvissareiro, a obra do autor polonês também já chegou por aqui até o crivo do público de teatro! Aos 22 de agosto de 1990, no Centro Cultural Banco do Brasil do Rio de Janeiro, estreava a primeira montagem brasileira de uma peça różewicziana: O Casamento Branco. A equipe responsável pela realização, composta por excelentes artistas da cena, faz supor de imediato um belo espetáculo, de construção apurada e vigoroso impacto sobre a plateia: na direção, Sergio Britto; direção corporal, Angel Vianna; música e direção musical, Cláudio Botelho; cenários e figurinos, Biza Viana; iluminação, Jorginho de Carvalho. E no elenco - não menos digno de nota -, Fabio Sabag, Othon Bastos, Suzana Faini, Tamara Taxman, Carolina Aguiar, Luciana Braga, Leonardo Bricio e Ivone Hoffmann, entre outros. ${ }^{5}$ Sem dúvida de grande interesse, uma tentativa de reconstrução analítica da montagem deve ser deixada para outra oportunidade. Um derradeiro aspecto da empreitada, contudo, possui relevância incontornável para a presente discussão. O texto levado ao palco resultou da prolífica oficina tradutória de Millôr Fernandes. Mais uma vez, o lastro autoral em jogo é de peso e permite supor sem receio que não faltaram qualidades ao traslado da peça utilizado na produção d'O Casamento Branco. Com a experiência que acumulou nas lides do traduzir - sobretudo a serviço do teatro -, Millôr terá dado forma, no mínimo, a um Różewicz brasileiro literariamente bem cuidado e perfeitamente funcional para a criação cênica dirigida por Sergio Britto.

4 Em polonês, respectivamente: Kartoteka (1960), Świadkowie (1962) e Białe Mał̇̌̀ństwo (1975).

5 O programa da peça está disponível no site Acervo Angel Vianna: < http://www.angelvianna. art.br/\#vida-e-obra/consolidacao-da-escola-angel-vianna/a-obscena-senhora-d-e-casamento-bran-

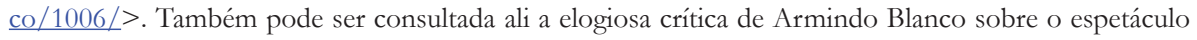
(publicada originalmente no jornal carioca O Dia, em 30 de agosto de 1990). No portal Sergio Britto Memórias, estão disponíveis algumas fotos da encenação: < http://www.sergiobritto.com/obra/teatro/ $\underline{\mathrm{ccbb} / \mathrm{O}-\mathrm{casamento}-\mathrm{branco} />}$ 
Só pôde fazê-lo, no entanto, sem conhecer a língua polonesa, por intermédio de alguma versão anterior de Białe Mał̇̌enstwo para outra língua. ${ }^{6}$

A questão com que deparamos neste ponto se revela crucial. Sendo certo que, a reboque da recepção do teatro de Różewicz no mundo, sua recepção entre nós já se pôs em marcha, uma tarefa decisiva ainda nos aguarda: traduzi-lo do original, inscrevê-lo no português do Brasil diretamente a partir do polonês. Desafio tanto maior, vale frisá-lo, porque tem em vista um duplo horizonte de destino: garantir publicação impressa (e/ ou eletrônica) das obras dramáticas do autor em tradução, para proveito de pesquisadores, professores e estudantes, quer da área das letras, quer da área do teatro - além de interessados em geral; e assegurar, ademais, matéria-prima dramatúrgica de préstimo para futuras iniciativas artísticas em nossos palcos. De uns tempos para cá, venho me dedicando a esse projeto. Conforme se antecipou, o objetivo aqui é dar a conhecer um pouco dos resultados já obtidos, uma pequena amostra do texto dramático różewicziano traduzido. Passaremos a ela assim que estejam respondidas, sucintamente, algumas perguntas básicas. Entre os mais de vinte títulos da dramaturgia do escritor, de que obra se trata? Que razões determinaram sua escolha? E por fim: que parâmetros orientaram seu processo tradutório?

Há de se ler em seguida um fragmento da terceira e última parte de Świadkowie albo Nasza Mała Stabilizacja (As Testemunhas ou Nossa Pequena Estabilização). A primeira edição da peça data de 1962. Até ali, só duas outras da lavra do autor haviam sido publicadas: além da já referida Kartoteka (O Fichário), em 1960, Grupa Laokoona (O Grupo de Laocoonte), em 1961. Cumpre lembrar, todavia, que sua trajetória como poeta vinha de bem antes. Para Karl Dedecius (2013, p. 175), estudioso, tradutor e editor dos escritos de Różewicz na Alemanha, o autor polonês "foi o primeiro que, buscando uma nova possibilidade de expressão na 'hora zero' após o término da Segunda Guerra Mundial, atingiu o objetivo" sua obra de estreia, Niepokój (Inquietude), de 1947, ofereceu "uma senha e uma carteira de identidade" (p. 175) aos sobreviventes, às hostes de náufragos "de uma geração tocada pelo cataclismo" 7 (p. 176; tradução minha). Mais de uma dezena

6 É bastante provável que Millôr tenha recorrido à versão inglesa da peça, que veio a lume em livro no início dos anos de 1980 (ver RÓŻEWICZ, 1983). Convém todavia que fique claro: não se trata de modo algum de incidir aqui em preconceitos superciliosos e simplistas acerca da assim chamada "tradução de segunda mão". Desdenhar desse tipo de operação tradutória constitui flagrante equívoco, o que se comprova, aliás, pelo próprio caso em exame: o pioneiro Casamento Branco de Różewicz dirigido por Sergio Britto hoje é história - e a tradução de Millôr faz parte dela.

7 [był pierwszym, który w "godzinie zero" po zakończeniu II wojny światowej szukając nowej możliwości wypowiedzi, osiagnął cel (...) hasło wywoławcze i dowód tożsamości (...) pokolenia dotkniętego katakliz- 
de livros de poemas antecede a publicação de Kartoteka. "[O]s alicerces da visão de mundo różewicziana", segundo outro especialista, "foram plantados muito sólida e duradouramente" (KELERA, 1988, p. 6) nesses volumes, aos quais subjazem as experiências e reflexões oriundas da guerra, da ocupação e da luta clandestina no Exército Nacional polonês (a Armia Krajowa), bem como a vigilante, aguda observação das vicissitudes do pós-guerra. " "A poesia precede o drama", portanto, mas "também - prepara o drama"10 (KELERA, 1988, p. 9), seja porque este herda maciçamente daquela seu substrato histórico e existencial, seja porque o trabalho de linguagem do poeta, em seu empenho de experimentação e invenção, se prolonga de certa maneira no trabalho de linguagem do dramaturgo.

Grosso modo, e resguardadas as especificidades de cada qual, bem entendido, a lírica e o drama de Różewicz são regidos por uma poética negativa. ${ }^{11}$ Assim como a tessitura de seus versos, que prima pela recusa e pelo despojamento, também a engenharia dramática do escritor opera sob um rigoroso signo de menos. O drama różewicziano se constitui como que pelo esvaziamento do drama, pela calculada erosão de traços distintivos costumeiros no gênero. Nem diálogo, por conseguinte, nem ação de moldes convencionais. O mais relevante aqui "se passa na esfera do não expresso e do não consumado", argumenta a pesquisadora Ewa Wąchocka (1997, p. 338), e "[n]o projeto ideal que persegue a Różewicz - na mudez e na imobilidade" (p. 338). ${ }^{12}$ Tchékhov e Beckett, está claro, definem marcos de referência inequívocos para o dramaturgo polonês. Tenhamos os dois em mente, além das demais considerações expostas, em face d'As Testemunhas.

mem]. Para evitar repetições, registro desde logo: todas as citações de obras estrangeiras no artigo em tradução minha.

8 [fundamenty Różewiczowskiej wizji świata (...) zostały już bardzo mocno i trwale osadzone]

9 Uma breve introdução à obra de Różewicz - à sua lírica, em particular - e traduções de alguns poemas do autor sobre a Shoah podem ser consultadas em SOUZA (2019a).

10 [Poezja wyprzedza dramat (...) także - przygotowuje dramat]

11 Nome de relevo entre os conhecedores da criação różewicziana, Stanisław Burkot sublinha que o escritor "trava uma incessante contenda com as convenções na arte [...] - em particular na poesia e no drama. O processo de esfacelamento de convenções fossilizadas é nele um ato criador - na destruição ou pela destruição surgem qualidades novas [prowadzi nieustanny spór z konwencjami w sztuce (...) - w szczególności zaś w poezji i w dramacie. Proces rozbijania skostniałych konwencji jest u niego aktem twórczym - w destrukcji czy poprzez destrukcję rodzą się nowe jakości]” (BURKOT, 2004, p. 134).

12 [rozgrywa się w sferze niewypowiedzianego i niedokonanego (...) W prześladującym Różewicza projekcie idealnym - w milczeniu i bezruchu] Essas características gerais, obviamente, tomam aspectos variados de peça a peça: seja no que toca às temáticas exploradas, seja no que respeita às formas e expedientes técnicos empregados. Para uma discussão em torno de outro título da dramaturgia do autor, ver SOUZA (2019b). 
A composição tripartite da peça sugeriu a Martin Esslin uma analogia com a forma da sonata: "[c] ada movimento contém-se em si mesmo, mas os três juntos produzem o efeito total desejado de variações sobre um tema de base, imagens inter-relacionadas"13 (ESSLIN, 1983, p. 322-323). Esse "tema de base" é introduzido por uma manobra inopinada, que instaura um jogo ficcional de peculiar complexidade. Sem que a cortina suba, especificam as didascálias, postam-se no palco Ela e Ele para recitar o poema (?!) intitulado "Nossa Pequena Estabilização". O texto que se segue alude com sarcasmo a um mundo que reencontrou sua suposta normalidade - temperatura média, ventos moderados, pernas cruzadas "no concerto/no teatro no avião" (RÓŻEWICZ, 1988, p. 180)... Uma nota de medo, entretanto, paira no ar e as palavras que encerram a primeira parte da obra - esse estranho limbo teatral, situado defronte da cortina, logo, ao mesmo tempo fora e dentro das coordenadas da cena - continuarão ressoando em ambas as partes restantes: "Nossa pequena estabilização/talvez seja só um sonho" (p. 182). O segundo e o terceiro movimentos da peça exibem situações de todo distintas uma da outra. No segundo, a fachada de modesto idílio do convívio doméstico de um casal vai deixando a descoberto tensões e fissuras insuspeitas. No terceiro, dois homens na sacada de um café, entre evasivas e banalidades, fazem o possível para manter as costas viradas a certo inconveniente que teima em reclamar sua atenção.

$\mathrm{Na}$ "estrutura do drama e da situação dramática, [na] estrutura do acontecimento e da sequência de acontecimentos, da imagem e da sequência de imagens", arrazoa o já citado Józef Kelera (1988, p. 11), é que discernimos o poeta no dramaturgo Różewicz. E, sobretudo, acrescenta o especialista, no "característico método de progressão do concreto rumo à metáfora" ${ }^{14}$ (p. 11). Compreensivelmente, a cifragem poético-metafórica d'As Testemunhas tem se aberto a diversas chaves de leitura e múltiplas sugestões de sentido. À luz da conjuntura social e política da Polônia, a obra logo assumiu feições de denúncia da falsa normalização da vida no país na fase inicial do governo de Władysław Gomułka como Primeiro Secretário do Partido Operário Unificado Polonês (Polska Zjednocz̧ona Partia Robotnicza) $\cdot{ }^{15} \mathrm{Em}$

13 [Each movement is self-contained, yet the three together produce the total desired effect of variations on a basic theme, interrelated images]

14 [struktura dramatu i sytuacji dramatycznej, struktura zdarzenia i sekwencji zdarzeń, obrazu i sekwencji obrazów (...) znamienna metoda postępowania od konkretu do metafory]

15 Segundo observa o polonista e tradutor Michel Masłowski (2002, p. 159), o título irônico da peça - "Nossa pequena estabilização" - passou a ser uma designação comum "do gomulkismo, espécie de equivalente do socialismo-goulash húngaro [du gomulkisme, sorte d'équivalent du "goulasch-socialisme" hongrois]". Sob Gomułka (Primeiro Secretário do PZPR do "Degelo", em 1956, até os protestos operários 
termos mais amplos, discutindo a peça no contexto do teatro do absurdo, Esslin a entendeu como um flagrante lírico da "brutalidade e insensibilidade" sob "a tênue crosta de normalidade do mundo pós-guerra"16 (ESSLIN, 1983, p. 323). Como tradutor do texto no Brasil, hoje, quero crer que não pouco de seu fascínio esteja atrelado a essas abordagens e às perspectivas por elas proporcionadas. Meu interesse mais premente, porém, é o potencial semântico acrescido ao texto, aqui, pela tradução, em resposta a outra conjuntura, às voltas com outros contextos e debates.

Ficou dito que na última parte da peça dois homens - chamados apenas de Segundo e Terceiro - têm sua atenção reclamada por um inconveniente. Vai rastejando na direção deles uma criatura agonizante, cujo aspecto, a princípio, é custoso determinar. Um cachorro de rua atropelado? Uma pessoa? Em sua meticulosa análise da obra, Halina Filipowicz depreende desses elementos dramáticos a conotação metafórica de uma espécie de prova ética e existencial. No que aparenta "um instante de terrificado reconhecimento"17 (FILIPOWICZ, 1991, p. 99), a criatura em agonia arranca do Segundo uma exclamação: "Pobre Jan!" (RÓŻEWICZ, 1988, p. 216) Seria este Jan, acaso, um hipotético Primeiro, "de quem o Segundo tomou o lugar? [...] Różewicz não concede explicações. O que importa é que [o Segundo e o Terceiro] se contentam em ser testemunhas. Nada, nem a fetidez do corpo em decomposição, pode impelir [os dois] a agirem"18 (FILIPOWICZ, 1991, p. 99). Embora concorde com as linhas gerais desse raciocínio, tenho uma objeção às considerações de Filipowicz. O Segundo e o Terceiro não se dignam a agir, nem tampouco a ser testemunhas. Não, pelo menos, em uma acepção forte da palavra. "Ainda está respirando?” (RÓŻEWICZ, 1988, p. 217) - pergunta o Terceiro ao Segundo. "Não sei. Se isso te interessa, venha aqui e olhe" (p. 218). Após um momento de silêncio, vem a resposta: "Não me interessa tanto assim" (p. 218). Omissão por inação, com efeito, só que mais ainda. Ouvidos moucos, ali onde não se poderia não ouvir; cegueira voluntária, ali onde não se poderia não ver. Acima de tudo, então, o drama de que Różewicz nos torna testemunhas talvez

de dezembro de 1970), "comprada de certo modo" [achetée en quelque sorte] na esteira de um período inicial de tímidas reformas, "toda contestação silenciou” [toute contestation s'est tue] (p. 159). Por isso, prossegue Masłowski, a fórmula różewicziana veio a funcionar também como uma palavra de ordem para os adversários do regime: "porque lhes causava vergonha" [parce qu’il leur faisait honte] (p. 159).

16 [brutality and callousness (...) the thin crust of the post-war world's normality]

17 [a moment of terrified recognition]

18 [whom the Second Man has unseated? (...) Różewicz offers no explanation. What matters is that both men are content to be witnesses. Nothing, not even the stench of the decomposing body, can compel them to take action] 
seja o drama do antitestemunho, da desfaçatez empedernida dos olhos e da boca fechados perante o que obriga ao contrário.

A tradução aqui apresentada partiu dessa premissa. E tomou impulso decisivo de uma urgência estética, ética e política: fazer o drama do antitestemunho różewicziano interpelar nossas circunstâncias e nossa história, tão pródigas, por seu turno, em indefectíveis Segundos e Terceiros... ${ }^{19}$ Quanto a minúcias de seu artesanato, enfim, que o gesto tradutório fale por si mesmo, em suas escolhas pontuais, tomadas isoladamente, bem como em seu rendimento de conjunto. A bivalência artística do texto dramático - sua espessura própria como gênero literário e a intrínseca pulsão cênica que o atravessa - foi o postulado geral determinante dos procedimentos e das soluções adotadas. ${ }^{20}$ Assim, se a elipse picota a sintaxe das frases traduzidas, por exemplo, ou se o português das personagens ecoa uma série de particularidades da língua falada no Brasil, tais recursos ${ }^{21}$ querem-se efetivos no âmbito da literatura, desde logo, sobre a quieta superfície da página, e, dada essa feliz eventualidade no futuro, em meio às dinâmicas da invenção coletiva da cena e da fruição compartilhada do espetáculo teatral.

19 Para a problemática teórica de fundo, ver as importantes reflexões sobre tradução e ativismo em TYMOCZKO (2014; especialmente o cap. 5: "Activism, Political Agency, and the Empowerment of Translators").

20 TOTZEVA (1995), BARAŃCZAK (2004) e FIGUEIREDO (1980) são alguns dos referenciais importantes aqui (posta de lado a matéria mais específica nos dois últimos casos: em Barańczak, sobre Shakeaspeare, e em Figueiredo, sobre o Tartufo, de Molière). Cada qual a seu modo, os três estudiosos evocados abordam a tradução do texto dramático a partir de um mesmo pressuposto: o vínculo constitutivo das obras desse gênero com a literatura e com a cena. Assim, discorrendo acerca das diretrizes que o guiaram pelos quase trinta anos de polimento de seu extraordinário Tartufo brasileiro, Figueiredo encarece a dupla visada de seus esforços: o palco e o leitor. Daí sua proposta de um "conceito poético-teatral" (p. 44) de fidelidade tradutória: "a estesia do original redescoberta em outras palavras de outro idioma" (p. 42), fornecendo "um máximo de veículos verbais" para uso do "jogo cênico" (p. 50).

21 Apenas a título de ilustração, algumas opções de linguagem - e os problemas tradutórios que elas tentaram equacionar - serão objeto de comentário a seguir, em notas, no decorrer do texto traduzido. Embora se reduza ao mínimo para não ralentar em demasia o passo da leitura, esse conjunto de notas deve permitir acesso à oficina da tradução em pontos mais nevrálgicos do texto dramático różewicziano. 


\section{As Testemunhas ou Nossa Pequena Estabilização}

Tadeusz Różewicz.

Tradução Marcelo Paiva de Souza

\section{PARTE III ${ }^{22}$}

[...] Em poltronas, dois homens de idade indefinida. Suas roupas são quase elegantes. Um deles está sentado de costas para a plateia; o outro, de frente. [...] As poltronas estão perto uma da outra, mas a distância entre elas é tal que os braços estendidos dos homens sentados não podem se tocar. Ouve-se o uivo distante e persistente de uma sirene. Como se tivesse chegado uma ambulância. Depois silêncio.

SEGUNDO endireita-se. Põe-se em uma posição mais cômoda. Cruza as pernas. Fica imóvel. Olha as pessoas. Não faz coisa alguma. Talvez reflita intensamente, mas quem vai saber...

TERCEIRO vê-se apenas o alto da cabeça careca no encosto. Vêe-se uma das mãos no braço da poltrona. Solta um "profundo suspiro de alivio". ${ }^{23}$ Ao que parece, percorreu um caminho longo e cansativo até chegar a esse lugar.

SEGUNDO endireita-se. Agora vemos suas duas mãos, os dedos apertam os bracos da poltrona.

TERCEIRO Aah. Respira.

SEGUNDO Está sentado? Hum?

TERCEIRO calado

SEGUNDO Finalmente.

TERCEIRO calado

SEGUNDO com animação Confortável?

22 O recorte efetuado no original buscou oferecer uma leitura que se bastasse a si mesma e que, na medida do possível, evidenciasse o leque de recursos e o modus operandi do dramaturgo: na configuração do espaço e das personagens, no fio das falas e dos silêncios, no humor - e na contundência.

23 As aspas irônicas (na expressão "profundo suspiro de alívio") e o comentário zombeteiro ("Talvez reflita intensamente, mas quem vai saber...") de imediato tornam perceptível nas didascálias a frequência muito particular de uma voz autoral e seu jogo com as convenções da dramaturgia. Mas não me afasto da norma escrita no texto secundário (ver, p. ex., o pronome átono enclítico nos verbos iniciando frases), para efeito de destaque do registro coloquial nas falas das personagens (ver adiante, entre diversos outros, o uso sistemático da forma reduzida da preposição "para" ou a próclise nos verbos pronominais em início de frase). 
TERCEIRO E você?

SEGUNDO Dá pra se acostumar. Não é lá muito firme.

TERCEIRO Não vai cair?

SEGUNDO Estou me segurando com as mãos e os pés.

TERCEIRO As unhas.

SEGUNDO Unhas e dentes. Sorri

TERCEIRO Não está achando muito apertado?

SEGUNDO Apertadaço, uma merda. ${ }^{24}$

TERCEIRO Tem alguma vista daí? Paisagens, pessoas?

SEGUNDO Uma... massa cinza, trêmula. Mas está muito longe. O tremor talvez seja do ar.

TERCEIRO Não está entediado?

SEGUNDO Não. Preciso ficar alerta.

TERCEIRO E você pode mudar de posição? Se virar?

SEGUNDO Não tenho necessidade.

TERCEIRO Está certo... Você não tem água aî?

SEGUNDO Não.

TERCEIRO E fogo?

SEGUNDO Não.

TERCEIRO Pena.

SEGUNDO Não.

TERCEIRO Tem uns fiapinhos de carne entre os meus dentes. Estão me irritando.

SEGUNDO Você se acostuma.

TERCEIRO Estão me irritando muito, você não tem aí um palito?

SEGUNDO Não.

TERCEIRO Procure.

SEGUNDO Não.

TERCEIRO Não o quê?

SEGUNDO calado

TERCEIRO Você está aí?

SEGUNDO Sim.

24 No original, "Cholernie ciasno" (algo como "Terrivelmente apertado"). O reforço expressivo coloquial é o advérbio "cholernie", de "cholera": cólera (a doença infecciosa) e, além disso, uma interjeição bastante usual na língua polonesa falada, de mesmo jaez que a nossa rotineira "merda". A solução brasileira que empreguei buscou cobrir um tanto desse espectro expressivo e semântico. Quiçá, temo, ao preço de oralizar um pouquinho demais... "Apertado pra cacete" - opção que ficou em segundo lugar na lista - tinha a desvantagem de tirar de cena "cholera" e derivados, reincidentes no decorrer do texto. 
TERCEIRO respira com alivio Bom.

SEGUNDO Estou, estou. Não tenha medo.

TERCEIRO Não gosto de solidão.

SEGUNDO Eu também não... para si mesmo Se mexeu de novo.

TERCEIRO Você disse alguma coisa?...

SEGUNDO Não.

TERCEIRO O que você disse?

SEGUNDO Nada.

TERCEIRO Mas o que é?

SEGUNDO Não sei.

TERCEIRO Um objeto, um bicho, uma nuvem?

SEGUNDO Um montinho escuro.

TERCEIRO Você disse que está se mexendo.

SEGUNDO Se aproximando, talvez.

TERCEIRO E se você for até lá?

SEGUNDO quase assustado Não, não.

TERCEIRO calado

SEGUNDO Não posso.

TERCEIRO E o que você está fazendo?

SEGUNDO Estou ocupado. Tenho um monte de problemas na cabeça. Eu vinha adiando tudo. Não posso sair daqui. Fora de questão.

TERCEIRO Deixe suas ocupações por um instante e veja o que tem lá.

SEGUNDO Não posso.

TERCEIRO calado

$[\ldots]$

SEGUNDO [...] Foi você que deu esse gemido?

TERCEIRO calado

SEGUNDO Com certeza foi essa infeliz dessa foca.

TERCEIRO Uma foca na rua?

SEGUNDO Pode ter saído de um tanque. E aliás, não é uma foca. É um cachorro. Agora estou vendo melhor.

TERCEIRO Um cachorro?

SEGUNDO É.

TERCEIRO Setter?

SEGUNDO Pointer.

TERCEIRO Pelo curto?

SEGUNDO Pelo crespo. 
TERCEIRO Bassê?

SEGUNDO Pelo liso.

TERCEIRO Pelo comprido?

SEGUNDO Mas como uiva, o bicho!

TERCEIRO Eu disse que é dobermann.

SEGUNDO Terra-nova.

TERCEIRO Poodle.

SEGUNDO Schnauzer.

TERCEIRO Está vendo ele direito?

SEGUNDO Não. Amanhã eu tenho de ir ao oculista.

TERCEIRO Eu, ao dentista.

SEGUNDO Imagine só, está se levantando.

TERCEIRO Você está vendo bem?

SEGUNDO Estou... interessante... após uma pausa Pele branca de vários tons.

TERCEIRO De um branco rosa até o amarelado.

SEGUNDO Corpo bem peludo, cabeça com pelo levemente ondulado.

TERCEIRO Às vezes quase liso; olhos e pelo de cor clara.

SEGUNDO Pelo preto, cacheado.

TERCEIRO Relativamente curto.

SEGUNDO Olhos muito escuros.

TERCEIRO Está vendo, eu falei.

SEGUNDO Agora está se equilibrando em duas patas.

TERCEIRO Com certeza fugiu de um circo.

SEGUNDO Não está se mexendo.

TERCEIRO Vai lá ver de uma vez.

SEGUNDO Não posso, você sabe muito bem que eu não posso sair do lugar.

TERCEIRO Esqueci.

SEGUNDO Você esquece rápido o que a gente te fala. Você sabe muito bem a luta que foi pra eu conseguir este lugar. Fiquei sem comer direito, sem jogar, sem pescar, sem amar e agora você vem querendo me convencer a largar meu lugar.

TERCEIRO Você está muito alterado. Se acalme.

SEGUNDO Quieto.

TERCEIRO Sabe o que me veio à cabeça?

SEGUNDO Espere. Eu tive a impressão...

TERCEIRO Claro, impressão... Deixe esse cachorro em paz. Estou curioso pra ouvir o que você vai achar da minha ideia.

SEGUNDO É um cachorro. 
TERCEIRO Jogue um osso pra ele e você vai ter sossego.

SEGUNDO Não tenho um osso. $\mathrm{E}$ acho que sossego aqui não vai ter mais.

TERCEIRO Então jogue uma pedra. Pra um bicho assim não faz diferença.

SEGUNDO Não. Após uma pausa Não. É impossível. Devo ter ouvido mal.

TERCEIRO Está vendo...

SEGUNDO Não estou vendo nada.

TERCEIRO Está chamando a gente.

SEGUNDO Latindo?

TERCEIRO História engraçada.

SEGUNDO Que merda, imagine essa: ele tem uma gravata no pescoço.

TERCEIRO Uma gravata?

SEGUNDO Uma gravata.

TERCEIRO Chegue mais perto.

SEGUNDO Não posso sair daqui, acho que já expliquei isso pra você. Situação idiota, justo com a gente vai acontecer uma dessas.

TERCEIRO O sujeito não tem um minuto de sossego.

SEGUNDO Você acredita?

TERCEIRO Acredito.

SEGUNDO No quê?

TERCEIRO Na ressurreição do corpo.

SEGUNDO Então você tem suas crenças?

TERCEIRO Tenho. E você?

SEGUNDO Não. Após uma pausa Levantou a cabeça. Estou vendo os olhos e a boca. Virou os olhos pro céu. De novo está rastejando.

TERCEIRO Jogue pra ele um pedaço de carne ou um cigarro.

SEGUNDO Está olhando pra mim.

TERCEIRO Impressão sua, você está muito sensível.

SEGUNDO Caiu. Está deitado. Deitado na própria bosta. Cavoucando com as patas.

TERCEIRO Quando desencavoucar ${ }^{25}$ me diga.

SEGUNDO O que você vai fazer agora?

TERCEIRO Tenho meus assuntos. Já preciso ir.

SEGUNDO Agora?

TERCEIRO Meu caminho também não é coberto de rosas.

25 Lancei mão de "Cavoucando"/“desencavoucar" (o segundo verbo, salvo engano, consistindo em um neologismo) para fazer frente ao jogo "Grzebie" /"się wygrzebie" no original. Por razões expressivas, a solução me pareceu indispensável; em polonês, no entanto, o verbo "wygrzebać" não é um neologismo... 
SEGUNDO passa um lenço no rosto Não estou entendendo.

TERCEIRO Estou dizendo que cada um de nós tem seus problemas. Já vou.

SEGUNDO Como assim “já vou”? Você quer ir embora? Agora?

TERCEIRO Não leve isso tão a sério.

SEGUNDO sorri com alivio Estou te dando um conselho, não saia daí. Não saia daí. É melhor ficar. Não saia daí. Você mesmo disse que se ajeitou passavelmente. Tem um lugar relativamente confortável, vista ampla, traje distinto, garagem. Ainda te restaram alguns ideais.

TERCEIRO funga

SEGUNDO O que você falou?

TERCEIRO Nada, continue.

SEGUNDO Continue o quê?

TERCEIRO funga $\mathrm{O}$ que é isso agora?... um cheiro ruim.

SEGUNDO Não estou sentindo nada.

TERCEIRO Como não está sentindo, se eu estou?

SEGUNDO dá de ombros

TERCEIRO Eu estou sentindo perfeitamente. Alguma coisa aqui está soltando um cheiro desagradável. Bem perto.

SEGUNDO Talvez você tenha pisado em algum cocô.

TERCEIRO Não... Mas é um cheiro horrível!

SEGUNDO Então não cheire.

TERCEIRO De algum modo eu preciso respirar.

SEGUNDO Respire pela boca, não pelo nariz. Pega o lenço, cobre a boca e o nariz:

TERCEIRO Aí do seu lado não se sente nada? Diga a verdade.

SEGUNDO com a voz abafada Te dou minha palavra de honra, não estou sentindo nada.

TERCEIRO Como assim, de honra?

SEGUNDO É, de honra.

TERCEIRO Honra?

SEGUNDO Honra.

TERCEIRO É. É o único valor que nos restou.

SEGUNDO É. É só o que nos restou.

TERCEIRO O quê?

SEGUNDO guarda o lenço $\mathrm{O}$ que você ia dizendo?

TERCEIRO Mas como fede. Tem alguma coisa podre aqui.

SEGUNDO Realmente.

TERCEIRO Não cheire.

SEGUNDO O ar está todo tomado.

TERCEIRO É simples: troque de lugar. 
SEGUNDO Não. Isso em nenhuma hipótese.

TERCEIRO Você está dizendo que o fedor é sufocante.

SEGUNDO Talvez eu me acostume.

TERCEIRO Eu te admiro.

SEGUNDO Vou tentar me acostumar.

TERCEIRO Eu admiro seu quase heroísmo.

SEGUNDO Escute, que tal a gente cantar um pouco? Vai ficar mais alegre. Um dois três... Juntos.

TERCEIRO calado

SEGUNDO Deve ter alguma carniça por aqui.

TERCEIRO E as autoridades fazem o quê? Onde está a opinião pública?

SEGUNDO O quê?

TERCEIRO A opinião pública.

SEGUNDO Pois é.

TERCEIRO Na segunda metade do século XX, bem no centro da cidade a carcaça de um bicho e ninguém dá a mínima.

SEGUNDO Pois é.

TERCEIRO Um cachorro? De que cachorro você está falando?

SEGUNDO Daquele que estava rastejando na sua direção.

TERCEIRO Na minha direção? Eu não sei de nada.

SEGUNDO como que assustado Oh, meu Deus!

TERCEIRO Como?

SEGUNDO inseguro, ri Pobre Jan! ${ }^{26}$

TERCEIRO Você falou comigo?

SEGUNDO Não... Enfiou o focinho na bosta.

TERCEIRO Pobre criatura.

SEGUNDO Está se mexendo ainda.

TERCEIRO E onde ele está agora?

SEGUNDO Seria melhor se alguém desse logo um fim nele.

TERCEIRO Perguntei a que distância está de nós.

SEGUNDO Está deitado aos meus pés.

TERCEIRO O quê?

26 Uma eventual montagem teria aqui um ponto interessantíssimo a considerar. Embora o nome polonês seja de pronúncia fácil, talvez se preferisse no palco a ressonância brasileira de um "Pobre João!" Ou talvez melhor ainda, trocando o nome: "Pobre Zée?" Para um modelo teórico de cooperação entre encenação e tradução, ver HÖRMANSEDER (2008). 
SEGUNDO Está deitado a um passo da minha perna.

TERCEIRO E o que é?

SEGUNDO Não sei.

TERCEIRO Mas agora você pode se mexer.

SEGUNDO Não posso.

TERCEIRO erguendo a voz. Como não pode? O que isso quer dizer? Você não pode dar um passo?

SEGUNDO Não posso sair do meu lugar.

TERCEIRO Ninguém vai tomar ele de você agora. Se mexa!

SEGUNDO Meu caro. Estou vendo que você está alterado. Sorri Percebo na sua voz algo novo... notas... emotivas. Você se indigna, ordena, grita.

TERCEIRO calado

SEGUNDO Espero que não comece a me dar lições de moral, hum? "Só um passo te separa", "se mexa!"... Caridoso! Ou quem sabe vai me lembrar minhas obrigações em relação ao próximo? Mande lá um sermão. À vontade... "Se mexa". Já te expliquei que não posso sair deste lugar.

TERCEIRO calmamente E se inclinar, você não pode?

SEGUNDO Não posso.

TERCEIRO O quê?

SEGUNDO Não estou com vontade. Pega o lenço e cobre a boca.

$[\ldots]$

TERCEIRO Ainda está respirando?

SEGUNDO Não sei. Se isso te interessa, venha aqui e olhe.

TERCEIRO calado

SEGUNDO Então?

TERCEIRO Não me interessa tanto assim. O que você está fazendo? Chamou o pronto-socorro?

SEGUNDO Lógico. ${ }^{27}$ Senta mais confortavelmente na poltrona

TERCEIRO Ele está dizendo alguma coisa?

SEGUNDO Não sei.

27 Lógico que sim - ou que não? A sirene de uma ambulância que parecia haver chegado, lembremos, soa logo na abertura da terceira parte da peça, conforme se lê nas didascálias iniciais. Entre muitas outras ocorrências similares no texto, o laconismo da fala do Segundo põe à mostra o papel chave da economia verbal na escrita dramatúrgica różewicziana. Menos palavras e tanto maior poder de sugestão, quer no plano da leitura, quer no plano das possibilidades de realização cênica. Sobre a fundamental problemática da expansão e da redução textual no âmbito do teatro polonês moderno traduzido, ver SCHULTZE; WEINHAGEN (2015). 
TERCEIRO Se você se inclinar um pouco, talvez ouça algo.

SEGUNDO Não posso.

TERCEIRO Fico me perguntando que aparência ele tem.

SEGUNDO Difícil determinar. Vai se decompondo muito rápido.

TERCEIRO Mas deve ter ainda alguma forma.

SEGUNDO Parece um saco cheio de carne podre.

TERCEIRO E a raça, não consegue identificar?

SEGUNDO Não.

TERCEIRO Não tem alguma marca, um anel, um documento?

SEGUNDO Não sei o que você está querendo dizer. É um escândalo que ninguém tenha limpado ainda essa carniça.

TERCEIRO Está falando dele como se fosse um cachorro.

SEGUNDO Era um cachorro.

TERCEIRO Tem certeza?

SEGUNDO Lógico. Cruza as pernas. Põe o lenço dobrado no bolso.

TERCEIRO Graças a Deus!

SEGUNDO O que você disse?

TERCEIRO Nada.

SEGUNDO Fico feliz que você esteja se recompondo. Eu não pensei que fosse se envolver tanto. Quase gritou comigo.

TERCEIRO Já deviam ter chegado.

SEGUNDO Pelo visto não estão com pressa.

Aumenta o burburinho de cidade grande. Silêncio. 


\title{
Świadkowie albo Nasza Mała Stabilizacja
}

\author{
Tadeusz Różenicz.
}

\section{CZĘŚĆ III}

[...] W fotelach siedzi dwóch meżcryżn w nieokreślonym wieku. Sa ubrani prawie elegancko. Jeden ₹ męzrcyyzn siedzi odwrócony do widowni tytem, drugi twarzq. [...]. Fotele stoja obok siebie, ale dzieli je taka odlegtość, ze nyciagniete rece siedzacych nie moga sie zetknać. Stychać dalekie przecciagte nycie syreny alarmowej. Jakby prayjechata karetka pogotowia. Potem cisza.

DRUGI poprawia sie. Sadowi sie nygodniej. Zakłada noge na noge. Siedz̨i nieruchomo. Patray na ludzi. Nic nie robi. Być može, mysli intensywnie, ale kto to może wiedziéc.

TRZECI widać tylko czubek tysej gtony nad oparciem fotela. Widać dton na porecisy. Wydaje ze siebie "głebokie westchnienie ulgi". Widocznie odbyt dtuga meczaca droge, zanim doszedt do tego miejsca.

DRUGI poprawia sie. Teraz widzimy jego dwie rece, palce zaciskaja sie na poreczach fotela.

TRZECI Taak. Odetchnat.

DRUGI Siedzisz? Co?

TRZECI milcry

DRUGI No, wreszcie.

TRZECI milcry

DRUGI ₹.osynieniem Wygodnie?

TRZECI A tobie?

DRUGI Można się przyzwyczaić. Stoi trochę niepewnie.

TRZECI Nie wypadniesz?

DRUGI Trzymam się rękami i nogami.

TRZECI Zębami.

DRUGI Zębami i pazurami. uśmiecha sie

TRZECI Nie jest ci za ciasno?

DRUGI Cholernie ciasno.

TRZECI A masz jakieś widoki? Krajobrazy, ludzi?

DRUGI Jakaś szara masa drży. Ale to bardzo daleko. Chyba powietrze tak drży.

TRZECI Nie nudzi ci się? 
DRUGI Nie. Muszę się pilnować.

TRZECI A możesz zmienić pozycję? Odwrócić się?

DRUGI Nie mam potrzeby.

TRZECI Masz rację... Nie masz tam u siebie wody?

DRUGI Nie.

TRZECI A ognia?

DRUGI Nie.

TRZECI Szkoda.

DRUGI Nie.

TRZECI Mam między zębami kawałki mięsa. Drażni mnie to.

DRUGI Przywykniesz.

TRZECI Bardzo mnie drażni, może masz zapałkę?

DRUGI Nie.

TRZECI Poszukaj.

DRUGI Nie.

TRZECI Co nie?

DRUGI milçy

TRZECI Ale ty tam jesteś?

DRUGI Tak.

TRZECI oddycha zulgq To dobrze.

DRUGI Jestem, jestem. Nie bój się.

TRZECI Nie lubię samotności.

DRUGI Ja też... do siebie To się znów poruszyło.

TRZECI Mówiłeś coś...

DRUGI Nie.

TRZECI Co mówiłeś?

DRUGI Nic.

TRZECI Ale co to jest?

DRUGI Nie wiem.

TRZECI Przedmiot, zwierzę, chmura?

DRUGI Małe, ciemne wzniesienie.

TRZECI Mówiłeś, że się porusza.

DRUGI Chyba się zbliża.

TRZECI A może tam podejdziesz?

DRUGI prawie wystraszony Nie, nie.

TRZECI milczy

DRUGI Nie mogę. 
TRZECI A co robisz?

DRUGI Jestem zajęty. Mam masę spraw na głowie. Wszystko odkładałem. Nie mogę ruszyć z miejsca. Nie ma mowy.

TRZECI Oderwij się na chwilę od swoich zajęć i zobacz, co tam leży.

DRUGI Nie mogę.

TRZECI milc $\not y$

$[\ldots]$

DRUGI [...] Czy to ty jęczałeś?

TRZECI milczy

DRUGI To pewnie ta nieszczęsna foka.

TRZECI Foka na ulicy?

DRUGI Mogła wyjść z basenu. Zresztą, to nie foka. To jest pies. Teraz widzę dokładniej. TRZECI Pies?

DRUGI Tak.

TRZECI Seter?

DRUGI Wyżeł.

TRZECI Krótkowłosy?

DRUGI Szorstkowłosy.

TRZECI Jamnik?

DRUGI Gładkowłosy.

TRZECI Długowłosy?

DRUGI Ale wyje to bydlę!

TRZECI Mówiłem ci, że to doberman.

DRUGI Wodołaz.

TRZECI Pudel.

DRUGI Brodacz monachijski.

TRZECI Czy go widzisz dokładnie?

DRUGI Nie. Muszę iść jutro do okulisty.

TRZECI A ja do dentysty.

DRUGI Wyobraź sobie, że się podnosi.

TRZECI Widzisz go dobrze?

DRUGI Tak... ciekawe... po chwili Skóra biała o różnych odcieniach.

TRZECI Od białoróżowego do żółtawego.

DRUGI Owłosienie ciała silne, włosy na głowie lekko faliste.

TRZECI Niekiedy prawie proste, barwa oczu i włosów jasna.

DRUGI Włosy czarne, skręcone.

TRZECI Stosunkowo krótkie. 
DRUGI Oczy bardzo ciemne.

TRZECI No widzisz, mówiłem.

DRUGI Teraz stoi na dwóch łapach.

TRZECI Uciekł pewnie z cyrku.

DRUGI Nie rusza się.

TRZECI Skocz i zobacz wreszcie.

DRUGI Nie mogę, przecież wiesz, że ja nie mogę opuścić miejsca.

TRZECI Zapomniałem.

DRUGI Szybko zapominasz o tym, co się do ciebie mówi. Przecież wiesz, z jakim trudem wywalczyłem sobie to miejsce. Nie dojadałem, nie grałem, nie łowiłem, nie kochałem, a teraz ty mnie namawiasz, żebym opuścił swoje miejsce.

TRZECI Jesteś bardzo wzburzony. Uspokój się.

DRUGI Cicho.

TRZECI Wiesz, co mi przyszło do głowy?

DRUGI Czekaj. Zdawało mi się...

TRZECI Oczywiście, że ci się zdawało... Zostaw tego psa w spokoju... Ciekaw jestem, co powiesz o moim pomyśle.

DRUGI To pies.

TRZECI Rzuć mu kość i będziesz miał spokój.

DRUGI Nie mam kości. Zdaje mi się, że i spokoju tu już nie będzie.

TRZECI To rzuć kamień. Takie bydlę nie rozróżni.

DRUGI Nie. po chwili Nie. To niemożliwe. Chyba się przesłyszałem.

TRZECI No widzisz.

DRUGI Nic nie widzę.

TRZECI On woła do nas.

DRUGI Szczeka?

TRZECI Zabawna historia.

DRUGI Cholernie, wyobraź sobie, że on ma na szyj krawat.

TRZECI Krawat?

DRUGI Krawat.

TRZECI Podejdź bliżej.

DRUGI Nie mogę się ruszyć, chyba ci to już wyjaśniłem. Głupia sytuacja, że też akurat nam musiało się to przytrafić.

TRZECI Człowiek nie ma chwili spokoju.

DRUGI Wierzysz?

TRZECI Wierzę.

DRUGI W co? 
TRZECI W ciała zmartwychwstanie.

DRUGI To ty jesteś wierzący?

TRZECI Tak. A ty?

DRUGI Nie. po chwili Podnosi głowę. Widzę oczy i usta. Podnosi oczy do nieba. Znów się czołga.

TRZECI Rzuć mu kawałek mięsa albo papierosa.

DRUGI On się patrzy na mnie.

TRZECI Zdaje ci się, jesteś przewrażliwiony.

DRUGI Upadł. Leży. Leży na własnym łajnie. Grzebie łapami.

TRZECI Jak się wygrzebie, to mi powiedź.

DRUGI Co teraz będziesz robił?

TRZECI Mam swoje sprawy. Muszę już iść.

DRUGI Teraz?

TRZECI Moja droga też nie jest usłana różami.

DRUGI wyciera twarz, chusteczka Nie rozumiem.

TRZECI Mówię, że każdy z nas ma swoje kłopoty. Idę.

DRUGI Jak to “idę”? Chcesz odejść? Teraz?

TRZECI Nie bierz tego tak poważnie.

DRUGI uśmiecha sie z ulga Radzę ci, nie ruszaj się. Nie ruszaj się. Lepiej zostań. Nie ruszaj się. Przecież sam mówiłeś, że się znośnie urzadziłeś. Masz stosunkowo wygodne miejsce, rozległe widoki, reprezentacyjne suknie, garaż. Zostało ci jeszcze trochę ideałów

TRZECI pociaga nosem

DRUGI Co mówisz?

TRZECI Ja nic, mów dalej.

DRUGI A o czym.

TRZECI pociaga nosem Co to znowu?... jakiś nieprzyjemny zapach.

DRUGI Nic nie czuję.

TRZECI Jak to nie czujesz, kiedy ja czuję?

DRUGI warusza ramionami

TRZECI Przecież ja czuję doskonale. Tutaj coś wydaje nieprzyjemną woń. Bardzo blisko.

DRUGI Może wlazłeś w jakieś odchody?

TRZECI Nie... Ale to paskudna woń!

DRUGI To nie wąchaj.

TRZECI Przecież muszę czymś oddychać.

DRUGI Oddychaj ustami, nie nosem. wyciaga chusteczke, prayktada do ust i nosa

TRZECI U ciebie nic nie czuć? Tylko mów prawdę.

DRUGI niewyrą́nie Daję ci słowo honoru, że nic nie czuję. 
TRZECI Jakiego znów honoru?

DRUGI No, honoru.

TRZECI Honoru?

DRUGI Honoru.

TRZECI Tak, to jedyna wartość, jaka nam została.

DRUGI Tak, to jedno nam zostało.

TRZECI Co?

DRUGI chowa chusteçkę Co mówisz?

TRZECI Ale to cuchnie. Tu coś gnije.

DRUGI Rzeczywiście.

TRZECI Nie wąchaj.

DRUGI Całe powietrze jest przesycone.

TRZECI Po prostu przenieś się na inne miejsce.

DRUGI Nie. To w ogóle nie wchodzi w rachubę.

TRZECI Mówisz, że smród cię dusi.

DRUGI Może przywyknę.

TRZECI Podziwiam cię.

DRUGI Spróbuję przywyknaćć

TRZECI Podziwiam twoje prawie bohaterstwo.

DRUGI Słuchaj, może coś zapiewamy. Będzie weselej. Raz dwa trzy... Razem...

TRZECI milcay

DRUGI Tu chyba gdzieś leży padlina.

TRZECI Co właściwie robią władze? Gdzie jest opinia społeczna?

DRUGI Co?

TRZECI Opinia społeczna.

DRUGI Właśnie.

TRZECI W drugiej połowy XX wieku w samym środku miasta leży padłe bydlę i nikogo to nic nie obchodzi.

DRUGI Właśnie.

TRZECI Pies? O jakim psie mówisz?

DRUGI O tym, który do ciebie czołgał.

TRZECI Do mnie? Nic nie wiem.

DRUGI jakby przestraszony O Boże!

TRZECI Proszę?

DRUGI śmieje się niepewnie Biedny Jan!

TRZECI Mówiłeś do mnie?

DRUGI Nie... Zarył się pyskiem w łajnie. 
TRZECI Biedne stworzenie.

DRUGI Rusza się jeszcze.

TRZECI A gdzie on teraz jest?

DRUGI Lepiej, żeby go ktoś dobił.

TRZECI Pytam się ciebie, jak daleko jest od nas.

DRUGI Leży u moich stóp.

TRZECI Co?

DRUGI Leży o krok od mojej nogi.

TRZECI A co to jest?

DRUGI Nie wiem.

TRZECI Przecież teraz możesz się ruszyć.

DRUGI Nie mogę.

TRZECI podniesionym głosem Jak to nie możesz? Co to znaczy? Nie możesz zrobić jednego kroku?

DRUGI Nie mogę się ruszyć z mojego miejsca.

TRZECI Teraz ci go nikt nie zajmie. Rusz się!

DRUGI Mój drogi. Widzę, że się podniecasz. uśmiecha się W twoim głosie słyszę jakieś nowe nuty... emocjonalne. Oburzasz się, rozkazujesz, krzyczysz.

TRZECI milczy

DRUGI Mam nadzieję, że nie zaczniesz mnie umoralniać, co? "Tylko jeden krok cię dzieli”, "rusz się!" Dobrodziej! A może mi zaczniesz przypominać o obowiązkach względem bliźnich. Kropnij kazanie. Użyj sobie... "rusz się". Już ci tłumaczyłem, że nie mogę się ruszyć z tego miejsca.

TRZECI spokojnie A pochylić się nie możesz?

DRUGI Nie mogę.

TRZECI Co?

DRUGI Nie chce mi się. wyciaga chusteçkę $i$ zastania sobie usta

$[\cdots]$

TRZECI Czy jeszcze oddycha?

DRUGI Nie wiem. Jeśli cię to interesuje, to chodź tu i zobacz.

TRZECI milczy

DRUGI No, co?

TRZECI Tak bardzo mnie nie interesuje. Co tam robisz? Zawiadomiłeś pogotowie?

DRUGI Oczywiście. zasiada wygodniej w fotelu

TRZECI Czy on coś mówi?

DRUGI Nie wiem.

TRZECI Jeśli się trochę pochylisz, to może coś usłyszysz. 
DRUGI Nie mogę.

TRZECI Ciekawe, jak wygląda.

DRUGI Trudno zidentyfikować. Rozkłada się bardzo szybko.

TRZECI Ale przecież ma jeszcze jakiś kształt.

DRUGI Wygląda jak worek pełen gnijącego mięsa.

TRZECI A rasy nie możesz rozpoznać?

DRUGI Nie.

TRZECI Nie ma jakiegoś znaczka, obrączki, dowodu?

DRUGI Nie wiem, o co ci chodzi. To jest skandal, że jeszcze nikt nie uprzątnął tej padliny.

TRZECI Mówisz o nim jak o psie.

DRUGI To był pies.

TRZECI Jesteś tego pewien?

DRUGI Oczywiście. zakłada noge na noge. Złożona chusteczke wkełada do kieszonki.

TRZECI Dzięki Bogu!

DRUGI Co mówisz?

TRZECI Nic.

DRUGI Cieszę się, że wracasz do formy. Wiesz, nie przypuszczałem, że aż tak się zaangażujesz. Prawie na mnie krzyczałeś.

TRZECI Już tu powinni być.

DRUGI Jakoś im się nie śpieszy.

Rośnie zgietk wielkiego miasta. Cisza.

\section{Referências bibliográficas}

ARAÚJO, Nélson. História do Teatro, $2^{\mathrm{a}}$ edição revista, ampliada e atualizada até 1980. Salvador: Empresa Gráfica da Bahia, 1991.

BARAŃCZAK, Stanisław. “Od Shakespeare’a do Szekspira”. In: Ocalone w Tłumaczeniu: Szkice o Warsztacie Tłumacza Poezji z Dodatkiem Małej Antologii Przekładów-Problemów, wyd. 3. Kraków: a5, 2004. pp. 148-172.

BURKOT, Stanisław. “Dramaturgia Tadeusza Różewicza”. In: Tadeusza Różewicza opisanie śmiata. Kraków: Wydawnictwo Naukowe Akademii Pedagogicznej, 2004. pp. 130-144.

DEDECIUS, Karl. "Ponowne Spotkanie z Tadeuszem Różewiczem”, przełożył Jacek Dąbrowski. In: Szekietko Ttumacza i Oko poety. Eseje, wybrał i wstępem opatrzył Andreas Lavaty. Kraków: Universitas, 2013. pp. 175-182. 
MASŁOWSKI, Michel. "L'Absurde dans le Théâtre de Tadeusz Różewicz”. In: DELAPERRIÈRE, Maria (Dir.). Absurde et Dérision dans le Théâtre Est-Européen. Paris: L'Harmattan, 2002. pp. 153-166.

ESSLIN, Martin. The Theatre of the Absurd, third edition (revised and enlarged). London/ New York: Penguin, 1983.

FIGUEIREDO, Guilherme. Tartufo 81. Rio de Janeiro: Civilização Brasileira, 1980.

FILIPOWICZ, Halina. A Laboratory of Impure Forms: the Plays of Tadeusz Rózewicz. New York: Greenwood Press, 1991.

HÖRMANSEDER, Fabienne. Text und Publikum. Kriterien für eine Bühnenwirksame Übersetzung im Hinblick auf eine Kooperation zwischen Translatologen und Bühnenexperten. Tübingen: Stauffenburg, 2008.

KELERA, Józef. "Od Kartoteki do Pułapki”. In: RÓŻEWICZ, Tadeusz. Teatr (Vol. 1). Kraków: Wydawnictwo Literackie, 1988. pp. 5-66.

RÓŻEWICZ, Tadeusz. Mariage Blanc and The Hunger Artist Departs, translated by Adam Czerniawski. London/New York: Marion Boyars, 1983.

. Świadkowie albo Nasza Mała Stabilizacja. In: Teatr (vol. 1), wyboru dokonał autor, wstępem poprzedził Józefa Kelera. Kraków: Wydawnictwo Literackie, 1988. pp. 177-218.

SCHULTZE, Brigitte; WEINHAGEN, Beata. "Między zyskiem a stratą. Redukcja i ekspansja w tłumaczeniu tekstów dla teatru na przykładzie polskich dramatów XX i XXI wieku. In: Przekłtadaniec, no 31, 2015. pp. 125-139. Página eletrônica: https://www.ejournals. eu/Przekladaniec/2015/Numer-31/. Consulta realizada em 28 de abril de 2020.

SOUZA, Marcelo Paiva de. “Tadeusz Różewicz: Fazer Poesia Depois de Oświęcim”. In: Contexto: Revista do Programa de Pós-Graduação em Letras da UFES, no 36, 2019a. pp. 239-268. Página eletrônica: http://periodicos.ufes.br/contexto/issue/view/953/show'Toc. Consulta realizada em 28 de abril de 2020.

__. "Pieszo (A Pé), de Sławomir Mrożek, e Pułapka (A Armadilha), de Tadeusz Różewicz: Drama, Testemunho, Memória e Tradução”. In: Anais Eletrônicos do XV I Congresso Internacional Abralic 2019: Circulação, Tramas \& Sentidos na Literatura. Brasília: Abralic, 2019b. pp. 3685-3696 (v. II). Página eletrônica: http://www.abralic.org.br/anais/. Consulta realizada em 28 de abril de 2020.

TOTZEVA, Sofia. Das theatrale Potential des dramatischen Textes: ein Beitrag zur Theorie von Drama und Dramenübersetzung. Tübingen: Gunter Narr Verlag, 1995.

TYMOCZKO, Maria. Enlarging Translation, Empowering Translators. London/New York: Routledge: 2014.

WĄCHOCKA, Ewa. "Rozdział VIII: Polska. Wstęp”. In: UDALSKA, Eleonora (Red.). O Dramacie. Od Sartre’a do Mrożka: Poetyki, Manifesty, Komentarze. Warszawa: Energeia, 1997. pp. 333-372. 